\title{
A simple protocol for the extraction and sequence analysis of DNA from study skin of museum collections
}

\author{
Nadia de Moraes-Barros and João Stenghel Morgante \\ Laboratório de Biologia Evolutiva e Conservação de Vertebrados, Departamento de Genética e Biologia \\ Evolutiva, Instituto de Biociências, Universidade de São Paulo, SP, Brazil.
}

\begin{abstract}
Museum collections have been widely used as sources of biological samples for molecular biology studies and there are several methodologies and techniques to obtain and analyze DNA from tissues archived in museums, but most of these protocols have been developed for a specific tissue or are commercial kits. We present a simple protocol for extracting and amplifying DNA segments from sloth museum specimens. With this simple protocol we analyzed DNA fragments from $64 \%$ of 64 skin samples from three-toed sloths (Bradypus variegatus and Bradypus tridactylus) archived in three different museums: 43 samples from the University of São Paulo Museum of Zoology (Museu de Zoologia da Universidade de São Paulo, MUZUSP) São Paulo, São Paulo, Brazil; 18 samples from the Emílio Goeldi Museum (Museu Paraense Emílio Goeldi, MPEG), Belém, Pará, Brazil; and 3 samples from the Museum of Vertebrate Zoology (MVZ) University of California, Berkeley, USA. The specimens sampled ranged in age from 18 to 108 years old. Our methodology allowed the recovery of up to $700 \mathrm{bp}$ of mitochondrial DNA and $400 \mathrm{bp}$ of nuclear genes. Thereafter, it is useful for genetic diversity studies of three-toed sloths and could be applied to other animals.
\end{abstract}

Key words: Bradypus, DNA, dried skins, museum specimens.

Received: May 10, 2006; Accepted: March 2, 2007.

Museum collections are very important sources of biological samples for genetic diversity studies which can be used to compare past and present diversity and detect possible loss of genetic diversity (Baker, 1994, Weber et al., 2000), an example of such a study being the Grinnell project at the Museum of Vertebrate Zoology, University of California, Berkeley, USA (see Internet Resources section).

Unfortunately, not all collections contain frozen or ethanol preserved tissues, the ideal material for obtaining DNA samples, with the most readily available materials being skulls and taxidermy specimens, prepared as stuffed or flated skins, namely study skins. Currently, several well known protocols are used to obtain and amplify DNA segments from museum specimens (Shedlock et al., 1997, Yang et al., 1997, Pichler et al., 2001, Junqueira et al., 2002) but most of these protocols require the use of commercial kits and special reagents whose costs are prohibitive for many researchers. Wisely et al. (2004) described a simple protocol for obtaining DNA from maxilloturbinate

Send correspondence to Nadia de Moraes-Barros. Laboratório de Biologia Evolutiva e Conservação de Vertebrados, Departamento de Genética e Biologia Evolutiva, Instituto de Biociências, Universidade de São Paulo, Rua do Matão, 277, 05508-090 São Paulo, SP, Brazil. E-mail: namoraes@ib.usp.br. bones and epithelial tissue (study skin) from museum specimens, this technique amplifying significantly more DNA segments from turbinate bone than from epithelium. However, the use of maxilloturbinate bones is only recommended for species larger than 100-300 g, when bones can be accessed without damaging the skull. For some museum specimens, in the absence of skulls or frozen or ethanol preserved tissues, study skins may be the only source of DNA. In this paper we provide an alternative and simple protocol for DNA extraction and posterior sequence analysis which we developed exclusively for study skins. We tested our methodology on skin samples from three-toed sloths (Xenarthra, Bradypodidae) and have shown that it is possible to amplify nuclear and mitochondrial DNA of up to $700 \mathrm{bp}$ and analyze a substantial number of specimens. We used 64 skin samples from three-toed sloths (Bradypus variegatus and Bradypus tridactylus, Xenarthra, Bradypodidae) archived in three different museums: 43 samples from the University of São Paulo Museum of Zoology (Museu de Zoologia da Universidade de São Paulo, MUZUSP) São Paulo, São Paulo, Brazil; 18 samples from the Emílio Goeldi Museum (Museu Paraense Emílio Goeldi, MPEG), Belém, Pará, Brazil; and 3 samples from the Museum of Vertebrate Zoology (MVZ) University of California, Berkeley, USA. The specimens ranged in age from 
18 to 108 years old (Table 1 ). Only opened study skins were used to collect tissue samples and tools were sterilized by flaming between each specimen sampled. For each specimen, a small fragment off dried skin $(1.5 \mathrm{~cm} \times 0.3 \mathrm{~cm})$ was sliced from the initial incision made during the preparation of the study skin, this procedure causing no significant loss of skin or any damage that could compromise further studies. All tissue fragments were transferred to sterile
Eppendorf tubes, identified and stored. One of the authors (NMB) collected samples from MUZUSP while museum staff collected samples from MPEG and MVZ.

The DNA extraction and amplification reactions were performed in a sterile environment free of DNA and all plastic material used in the procedure was exposed to UV light and all surfaces wiped with a $50 \%(\mathrm{v} / \mathrm{v})$ solution of bleach (containing $1.25 \% \mathrm{w} / \mathrm{v} \mathrm{NaClO}$ ) and $70 \%(\mathrm{v} / \mathrm{v})$ etha-

Table 1 - Success of DNA analysis using 64 skin samples from three-toed sloths (Bradypus variegatus and Bradypus tridactylus) archived in three different museums: 43 samples from the University of São Paulo Museum of Zoology (Museu de Zoologia da Universidade de São Paulo, MUZUSP) São Paulo, São Paulo, Brazil; 18 samples from the Emílio Goeldi Museum (Museu Paraense Emílio Goeldi, MPEG), Belém, Pará, Brazil; and 3 samples from the Museum of Vertebrate Zoology (MVZ), University of California, Berkeley, USA. The frequencies of success accumulated until and after each collection year were compared using Fisher's exact tests (Fisher's $P$ ). Statistically significant $P$ values are in boldface.

\begin{tabular}{|c|c|c|c|c|}
\hline \multirow{2}{*}{$\begin{array}{l}\text { Collection } \\
\text { year }\end{array}$} & \multirow{2}{*}{$\begin{array}{l}\text { Number of specimens and } \\
\text { museum catalog number }\end{array}$} & \multicolumn{2}{|c|}{ Accumulated success } & \multirow[b]{2}{*}{ Fisher's $P(\alpha=0.05)$} \\
\hline & & Until collection year & After collection year & \\
\hline $1898^{*}$ & 1: MUZUSP 281 & 0 & 0.651 & 0.359 \\
\hline 1902 & 3: MUZUSP 783, 785, 799 & 0 & 0.683 & 0.014 \\
\hline 1905 & 3: MUZUSP 1811, 1812, 1869 & 0.143 & 0.702 & 0.007 \\
\hline 1908 & 1: MUZUSP 2597 & 0.222 & 0.709 & 0.008 \\
\hline 1907 & 2: MUZUSP 2755, 2892 & 0.3 & 0.704 & 0.027 \\
\hline 1910 & 4: MUZUSP 2893, 2894, 2897, 2898 & 0.5 & 0.68 & 0.228 \\
\hline 1917 & 1: MUZUSP 3897 & 0.563 & 0.667 & 0.551 \\
\hline 1918 & 1: MUZUSP 3534 & 0.529 & 0.681 & 0.377 \\
\hline 1919 & 2: MUZUSP 3535, 19915 & 0.474 & 0.711 & 0.091 \\
\hline 1932 & 1: MVZ 95064 & 0.5 & 0.705 & 0.106 \\
\hline 1933 & 1: MUZUSP 3835 & 0.524 & 0.698 & 0.267 \\
\hline 1935 & 1: MUZUSP 5302 & 0.5 & 0.714 & 0.107 \\
\hline 1936 & 2: MUZUSP 5426, 5428 & 0.5 & 0.725 & 0.106 \\
\hline 1937 & $\begin{array}{l}\text { 6: MUZUSP } \\
3896,5300,5301,5303,5429,5434\end{array}$ & 0.483 & 0.771 & 0.021 \\
\hline 1950 & 1: MUZUSP 7205 & 0.467 & 0.794 & 0.009 \\
\hline 1951 & 1: MUZUSP 7370 & 0.484 & 0.788 & 0.018 \\
\hline 1952 & 3: MUZUSP 7528, 7529; MVZ 116806 & 0.5 & 0.8 & 0.019 \\
\hline 1955 & 2: MPEG 2354, 2358 & 0.528 & 0.786 & 0.039 \\
\hline 1957 & 4: MUZUSP 8247, 8304, 6460; MPEG 2357 & 0.525 & 0.833 & 0.016 \\
\hline 1958 & 1: MPEG 2356 & 0.537 & 0.826 & 0.029 \\
\hline 1960 & 3: MPEG 1742, 1840, 8746 & 0.545 & 0.85 & 0.025 \\
\hline 1962 & 1: MUZUSP 13500 & 0.556 & 0.842 & 0.045 \\
\hline 1964 & 2: MUZUSP 10417; MPEG 2693 & 0.574 & 0.824 & 0.083 \\
\hline 1966 & 3: MUZUSP 13497, 13498, 13501 & 0.58 & 0.857 & 0.066 \\
\hline 1972 & 1: MUZUSP 13502 & 0.588 & 0.846 & 0.111 \\
\hline 1974 & 1: MUZUSP 13505 & 0.596 & 0.833 & 0.185 \\
\hline 1977 & 2: MUZUSP 13506; MPEG 10232 & 0.611 & 0.8 & 0.308 \\
\hline 1978 & 5: MPEG 10233, 10234, 10235, 10236, 10237 & 0.644 & 0.6 & 1.000 \\
\hline 1979 & 1: MVZ 157796 & 0.65 & 0.5 & 0.614 \\
\hline 1981 & 2: MPEG 10299, 13686 & 0.645 & 0.5 & 1.000 \\
\hline 1986 & 1: MPEG 21327 & 0.635 & 1 & 1.000 \\
\hline 1988 & 1: MPEG 23159 & 0.641 & & \\
\hline
\end{tabular}

*This sample was collected before 1898 . 
nol. Prior to DNA extraction the skin samples were cleaned, the fur removed and the outer layer of the skin scraped with a sterilized scalpel to remove the surface layer (which could have contained contaminant DNA). The skin sample was then transferred to an Eppendorf tube, washed three times with sterile milli $\mathrm{Q}$ water, three times with ethanol 70\% (v/v) and rinsed three times with sterile milli Q water and then cut into small pieces. One duplicate set of skin samples was hydrated before digesting by incubating each sample for $24 \mathrm{~h}$ in $1 \mathrm{~mL}$ of TE solution (containing Tris $10 \mathrm{mM}$ and EDTA $1 \mathrm{mM}, \mathrm{pH} 7.6)$, washing with $70 \%(\mathrm{w} / \mathrm{v})$ ethanol and milli $\mathrm{Q}$ water and hydrating again in TE solution for a further $24 \mathrm{~h}$. A second duplicate of the tissue fragments set received no hydration. In both cases, DNA was extracted using an adapted Proteinase K and Phenol protocol (Sambrook et al., 1989). The skin samples were digested in TNE solution (containing Tris $\mathrm{HCl} 10 \mathrm{mM}, \mathrm{pH}$ 8; $\mathrm{NaCl} 400 \mathrm{mM}$; EDTA $2 \mathrm{mM}$, pH 8.0) plus SDS $1 \%$ and Proteinase $\mathrm{K} 8 \mathrm{mg} \mathrm{mL}^{-1}$ at $55^{\circ} \mathrm{C}$ for $36 \mathrm{~h}$ or until the tissue was completely digested. The DNA was extracted with one volume of phenol:cloroform:isoamilic alcohol (25:24:1) and centrifuged for $10 \mathrm{~min}$ at $12000 \mathrm{rpm}$, after which the supernatant solution was transferred to another tube and the DNA precipitated by adding two volumes of $100 \%$ ethanol and maintaining the solution at $-20{ }^{\circ} \mathrm{C}$ for $16 \mathrm{~h}$ before discarding the ethanol and resuspending the pellet in $50 \mu \mathrm{L}$ of TE solution. All DNA extraction procedure was performed with a negative control tube (blank extract) containing only digestion reagents. DNA sample amounts and quality as well as blank extracts were analyzed by electrophoresis.

To amplify and sequence segments of both mitochondrial and nuclear DNA we tested various primers (Table 2).
Three primer pairs were tested for segments A, B and C of the mitochondrial DNA (mtDNA) control region (up to $200 \mathrm{bp}$ ), these overlapping segments together encompass $400 \mathrm{bp}$ of the sloth mtDNA control region segment. Primers H-15978 and L-15445 were tested for their ability to amplify the entire $400 \mathrm{bp}$ of the sloth mtDNA control region segment. Sample DNA amplified by the H-15978 and L-15445 primers (19 of 64 samples) were also subjected to amplification with the L/H, L2510/B16S-H and F1Iint/R2 primer pairs (Table 2).

The polymerase chain reactions (PCR) were carried out in a $10 \mu \mathrm{L}$ final volume using 1.25 units of Taq polymerase (Invitrogen), $\mathrm{MgCl}_{2} 2.5 \mathrm{mM}, 0.8 \mathrm{mM}$ dNTPs, $1 \mu \mathrm{M}$ of each primer, $1.6 \%(\mathrm{v} / \mathrm{v})$ bovine serum albumin (USB) and $1 \mu \mathrm{L}$ of DNA template under different temperatures and times according to the primer combinations used (Table 2). The PCRs consisted of $94^{\circ} \mathrm{C}$ for $10 \mathrm{~min}, 40$ cycles of $94{ }^{\circ} \mathrm{C}$ for $45 \mathrm{~s}, 46-61{ }^{\circ} \mathrm{C}$ for $45-50 \mathrm{~s}, 72{ }^{\circ} \mathrm{C}$ for $40-60 \mathrm{~s}$, followed by a final extension at $72{ }^{\circ} \mathrm{C}$ for $10 \mathrm{~min}$. For each set of PCR reactions we used two negative controls, one containing water only (the water blank) and a reaction mixture containing the blank extract. A re-amplification test, including negative controls, was also carried out using the PCR products as templates. Amplification reactions and negative controls were analyzed by electrophoresis. All PCR products were purified using Shrimp Alkaline Phosphatase and Exonuclease I (USB). Sequencing reactions were conducted using the BigDye Kit (Applied Biosystems) and $2 \mu \mathrm{L}$ of PCR product. Sequencing reactions were precipitated using isopropanol and run on $\mathrm{ABI} 377$ and $\mathrm{ABI}$ 3100 automated sequencers (Applied Biosystems). Each

Table 2 - Primer details, annealing temperature $(\theta)$ and rate of success expressed as the number of valid sequences divided by the number of specimens tested.

\begin{tabular}{|c|c|c|c|c|c|c|}
\hline Primers & References & Gene segment & $\begin{array}{l}\text { Length } \\
\text { (bp) }\end{array}$ & Primer sequence $5 \rightarrow 3$ & $\begin{array}{c}\theta \\
\left({ }^{\circ} \mathrm{C}\right)\end{array}$ & Success \\
\hline $\begin{array}{l}\text { L-15445 } \\
\text { BrDl-H4N }\end{array}$ & Douzery and Randi (1997)* & A & 170 & $\begin{array}{l}\text { ACCAATGACATGAAAAACCATCGTTG } \\
\text { GCATGGGGAATATAAATGTATGCACG }\end{array}$ & 50 & $34 / 64$ \\
\hline $\begin{array}{l}\text { BrDl-L3 } \\
\text { BrDl-H3N }\end{array}$ & $*$ & B & 200 & $\begin{array}{l}\text { TATGCTTTATCGTGCATACATTTA } \\
\text { GAGGGATACTTATTGGATGGATTGCTG }\end{array}$ & 47 & $31 / 64$ \\
\hline $\begin{array}{l}\text { BrD1-L2N } \\
\text { H-15978 }\end{array}$ & $\begin{array}{l}* \\
\text { Arnason et al. (1997) }\end{array}$ & $\mathrm{C}$ & 160 & $\begin{array}{l}\text { CCAGTCACCATGCTTATCACCTCC } \\
\text { GTATGGGTGGAATGGAATTTT }\end{array}$ & 50 & $34 / 64$ \\
\hline $\begin{array}{l}\text { L-15445 } \\
\text { H-15978 }\end{array}$ & $\begin{array}{l}\text { Douzery and Randi (1997) } \\
\text { Arnason et al. (1997) }\end{array}$ & mtDNA- control region & 400 & $\begin{array}{l}\text { ACCAATGACATGAAAAACCATCGTTG } \\
\text { GTATGGGTGGAATGGAATTTT }\end{array}$ & 51 & $19 / 64$ \\
\hline $\begin{array}{l}\mathrm{L} \\
\mathrm{H}\end{array}$ & Greenwood et al. (2001) & mtDNA-cytochrome b & 650 & $\begin{array}{l}\text { ACCAATGACATGAAAAACCATCGTTG } \\
\text { GTATGGGTGGAATGGAATTTT }\end{array}$ & 46 & $8 / 19$ \\
\hline $\begin{array}{l}\text { L-2510 } \\
\text { B16S-H }\end{array}$ & Barros et al. $(2003)^{\dagger}$ & mtDNA-16S & 700 & $\begin{array}{l}\text { CGCCTGTTTATCAAAAACAT } \\
\text { TGGATTGCTCCGGTCTGAACTCA }\end{array}$ & 50 & $4 / 19$ \\
\hline $\begin{array}{l}\text { F1 Iint } \\
\text { R2 }\end{array}$ & Baker et al. (2000) & Nuclear Rag 2 & 400 & $\begin{array}{l}\text { GGYTCCACTCCCTTTGAAGA } \\
\text { GRAAGGATTTCTTGGCAQGGAGT }\end{array}$ & 61 & $2 / 19$ \\
\hline
\end{tabular}

*The design of primers A, B, and C segments was based on $400 \mathrm{bp}$ of sloth mtDNA control region sequences obtained from high quality DNA extracted from fresh blood samples (Moraes-Barros et al., 2006).

'Primer B16S-H was designed based on Dasypus novemcinctus (Arnason et al., 1997) and the Bradypus tridactylus (Genbank direct submission AY960979) complete mitochondrial genome. 


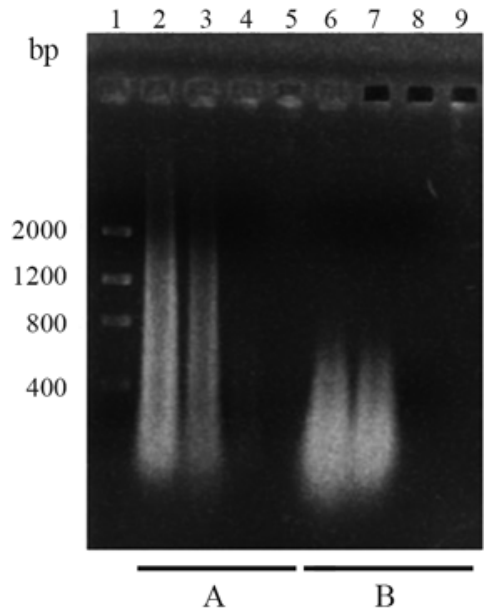

Figure 1 - Electrophoresis results of three different sloth skin DNA samples obtained with prior hydration ( $\mathrm{A}=$ lanes 2, 3 and 4$)$ and without prior hydration $(\mathrm{B}=$ lanes 6,7 and 8$)$. Lane $1=$ low mass DNA molecular marker. Lanes 5 and $9=$ blank. Some DNA samples obtained using the hydrating step show an increase in higher molecular size fragments. Lane 4 shows only a small amount of DNA and in lane 8 the DNA concentration is so low that it cannot be seen in the gel. All lanes were loaded with $4 \mu \mathrm{L}$ of DNA sample.

specimen was submitted to at least two independent PCR and sequencing reactions to assure the quality of sequences and avoid analyzing non-specific amplifications involving fragmented DNA. The duplicated sequences were first compared within specimens and then compared to control sequences: mtDNA control region sequences obtained with DNA extracted from 43 fresh sloth blood samples, described in Moraes-Barros et al. (2006) and an additional 20 sequences each from the mtDNA-Cytocrome $b, \mathrm{mtDNA}$ $16 \mathrm{~S}$ and nuclear RAG2 regions obtained from high quality sloth DNA segments. Valid sequences were considered to be clear DNA sequences, without specimen ambiguities, that could be aligned with control DNA sequences and were classified according to their length as short (mtDNA $\mathrm{A}, \mathrm{B}$, and $\mathrm{C}$ segments) or long DNA (nuclear and mtDNA segments ranging from 400 to $700 \mathrm{bp}$ ) sequences. Statistical analyses were performed to test for successful amplification as a function of the age of the sample (i.e. the date of collection of the museum specimen) and the successful amplification data set was arranged in chronological order starting with the oldest specimen. The frequencies of success accumulated until and after each collection year were compared using Fisher's exact tests (Fisher, 1958). A sample resulting in at least one DNA valid sequence for one gene was considered successful (Table 1).

The DNA extraction tests showed that when the skin samples were hydrated all the tissues were completely digested in less than $24 \mathrm{~h}$ but without hydration only $60 \%$ of samples were digested after $36 \mathrm{~h}$ and $40 \%$ of samples required $72 \mathrm{~h}$ for complete digestion. Hydrated samples also resulted in a larger final amount of sample DNA (data not shown) and for some specimens hydrated samples resulted in an increased number of high molecular weight (longer) DNA segments (Figure 1). It was clear that prior hydration resulted in better tissues digestion so we used this in all subsequent DNA extractions and all PCR amplifications were carried out using DNA samples from hydrated tissues. We assumed that no contamination occurred during the extraction of DNA or PCR amplification since there were no positive fluorescent results on electrophoresis when analyzing the various blanks. When the re-amplification test was performed only PCR with gene segments as templates showed positive results. All PCR performed with the negative controls as templates showed no fluorescens after electrophoresis.

Our results showed positive amplification and sequencing of at least one DNA segment for $64 \%$ of the skin samples tested. We obtained valid sequences for $52 \%$ of the 192 possible short mtDNA control region segments $(64 \times 3$ overlapping segments). We did not test for significant difference between the success of the DNA extraction and PCR protocol and methods previously described by other authors, but our protocol resulted in a substantial number of valid sequences simply considering the proportion of success. We could also analyze $27 \%$ of the possible 121 long sequences of both nuclear and mtDNA (Table 2), while most molecular studies performed using degraded DNA do not report positive results for sequences longer than $250 \mathrm{bp}$. In comparison, our methodology gave positive amplification of $400 \mathrm{bp}$ segments of nuclear DNA and of mtDNA segments ranging from 160 to $700 \mathrm{bp}$. We believe that the success on long sequences were possible due the amount of high molecular size fragments present in some of our DNA samples. Only samples resulting in long valid sequences presented high molecular size DNA fragments after extraction, but we cannot categorically affirm that the DNA extraction protocol or the hydrating period was responsible for these results. Likewise, we cannot assume that it is impossible to amplify and sequence long DNA segments using other DNA extraction methods because we did not test any other methodology to amplify and sequence long DNA segments nor have previous articles describing the use of DNA from museum specimen. In our experiments hydration allowed for better digestion and increases the amount of final DNA but did not assure the presence of long DNA segments in the extracted samples. The recovery of long DNA segments after extraction may depend on several variables, such as how the skin is prepared, storage and time since specimen collection and any treatment previously applied to the museum specimen. Since some of this information is not available for all specimens in museum collections we could not perform appropriate tests to verify any possible correlations.

Statistical analysis showed that recent museum specimens tended to show higher rates of successful DNA analysis, but there was no effect of time on success for specimens ranging from 18 to 42 years old $(\mathrm{p}>0.05)$. This implies 
that, for our data set, all museum specimens collected after 1964 can be considered as recent specimens for the purpose of DNA analysis. The significance of the above results disappeared when we applied the sequential Bonferroni correction to compensate for inflated experiment-based error due to the relatively large number of Fisher exact tests performed (Rice, 1989) but the trend inferred above was still clearly apparent. However, we found that only recent museum specimens (our classification, see above) gave valid long sequences for the nuclear Rag2 (400 bp), mtDNA cytb (650 bp) and 16S (700 bp) primers. Since all the specimens were subjected to the same DNA extraction and PCR protocols we must conclude that the success of long sequence retrieval must have been due to the age of the specimen. Thus it seems that only relatively recent specimens should be used when the aim is to analyze long DNA segments. On the other hand, despite the low rate of success, old museum species are still good sources for obtaining short DNA segments.

In this paper we have reported an appropriate, efficient and simple method for the DNA analysis for researchers who do not have access to commercial kits yet intend to use museum specimens, especially skins, in molecular studies. It is important to mention that this protocol has been tested only on sloth specimens and needs to be tested on different taxa to study its efficiency. We have also shown that hydrating skins is essential to improving the digestion of tissues prior to DNA extraction. Our statistical analysis indicates that recent samples tended to show higher rates of success in DNA extraction and analysis. However, it may be promising to test the efficacy of this protocol on every museum sample when few specimens are available and when analyzing short DNA sequences. It should also be remembered that the use of older specimens may be valuable when comparing past and present genetic diversity values.

\section{Acknowledgments}

We thank James L. Patton, Mario de Vivo, Caroline C. Aires, Peter Mann de Toledo, Ronaldo Borges Barthem, Ima Célia Vieira, José de Souza e Silva Júnior and Adê Avelar for museum specimen samples and information. We also thank Paulo Otto for helping with the statistics and three anonymous referees for helpful comments on the manuscript. This paper is a result of a phylogeographic study on three-toed sloths supported by the Brazilian agency Fundação de Amparo à Pesquisa do Estado de São Paulo (FAPESP) under fellowships and grants numbers 99/01310-4, 00/14629-8, 00-13213-2 and 03/03212-7.

\section{References}

Arnason U, Gullberg A and Janke A (1997) Phylogenetic analysis of mitochondrial DNA suggest a sister group relationship between Xenarthra (Edentata) and Ferungulates. Mol Biol Evol 14:762-768.

Baker RJ (1994) Some thoughts on conservation, biodiversity, museums, molecular characters, systematics, and basic research. J. Mamm 75:277-287.

Baker RJ, Porter CA, Patton JC and van den Bussche RA (2000) Systematics of bats of the family Phyllostomidae based on $R A G 2$ DNA sequences. Occas Pap Tex Tech Univ Mus 202:1-16.

Barros MC, Sampaio I and Schneider H (2003) Phylogenetic analysis of $16 \mathrm{~S}$ mitochondrial DNA data in sloths and anteaters. Genet Mol Biol 26:05-12.

Douzery E and Randi E (1997) The mitochondrial control region of Cervidae: Evolutionary patterns and phylogenetic content. Mol Biol Evol 14:1154-1166.

Fisher RA (1958) Statistical Methods for Research Workers. 13th edition. Hafner Publ Co Inc, New York, 356 pp.

Greenwood AD, Castresana J, Feldmaier-Fuchs G and Paabo S (2001) A molecular phylogeny of two extinct sloths. Mol Phylogenet Evol 18:94-103.

Junqueira ACM, Lessinger AC and Azeredo-Espin AML (2002) Methods for the recorvery of mitochondrial DNA sequences from museum specimens of myiasis-causing flies. Med Vet Entomol 16:39-45.

Moraes-Barros N, Silva JAB, Miyaki CY and Morgante JS (2006) Comparative phylogeography of the Atlantic forest endemic sloth (Bradypus torquatus) and the widespread three-toed sloth (Bradypus variegatus). Genetica 126:189-198.

Pichler FB, Dalebout ML and Baker CS (2001) Nondestructive DNA extraction from sperm whale teeth and scrimshaw. Mol Ecol Notes 1:106-109.

Rice WR (1989) Analyzing tables of statistical tests. Evolution 43:223-225.

Sambrook J, Fritsch EF and Maniatis T (1989) Molecular Cloning: A Laboratory Manual. v. 3. Cold Spring Harbor Laboratory Press, New York.

Shedlock AM, Haygood MG, Pietsch TW and Bentzin P (1997) Enhanced DNA extraction and PCR amplification of mitochondrial genes from formalin-fixed museum specimens. Biotechniques 22:394-6.

Yang, H, Golenberg EM and Shoshani J (1997) Proboscidean DNA from museum and fossil specimens: An assessment of ancient DNA extraction and amplification techniques. Biochem Genet 35:165-179.

Weber DS, Stewart BS, Garza JC and Lehman N (2000) An empirical genetic assessment of the severity of the northen elephant seal population bottleneck. Curr Biol 10:1287-1290.

Wisely SM, Maldonado JE and Fleischer RC (2004) A technique for sampling ancient DNA that minimizes damage to museum specimens. Conserv Genet 5:105-107. 2004.

\section{Internet Resource}

The Grinnell project: http://mvz.berkeley.edu/Grinnell/Yosemite_Survey_2005.html. Associate Editor: Luiz Lehmann Coutinho 